ORIGINAL ARTICLE

\title{
Pedicle viability as the determinant factor for conversion to free nipple graft
}

\author{
Al-shaham AA CABS
}

\begin{abstract}
Al-shaham AA. Pedicle viability as the determinant factor for conversion to free nipple graft. Can J Plast Surg 2010;18(1):e1-e4.
\end{abstract}

INTRODUCTION: Women with extremely large breasts have many complaints. Reduction mammaplasty improves shape and relieves physical symptoms and alleviates psychological complaints. Mammaplasty is a an evolving technique; no single method is ideal or suitable for all breasts. Many techniques are advocated for reduction mammaplasty, including the superior, verti$\mathrm{cal}$, horizontal, lateral and inferior (the most popular) pedicle techniques. Even after 60 years of development in breast reduction techniques, there are still reported incidences of nipple-areola complex (NAC) necrosis.

OBJECTIVE: To assess the perioperative conversion to free nipple graft to prevent the complication of nipple necrosis when pedicle viability is grossly compromised.

METHODS: Between January 2002 and March 2006, 66 patients (132 breasts) underwent reduction mammaplasty using the inferior pedicle technique. The patients presented with breast gigantism and required excision of more than $1000 \mathrm{~g}$ of breast tissue per side. The mean patient age was 34.81 years. Patients had neck, shoulder and back pain as well as psychological complaints. Data regarding sternal notch-to-nipple distances and inframammary fold-to-nipple distances were recorded preoperatively and postoperatively. The weights of the excised breast tissue from either side were recorded. Viability of the pedicle flap was carefully monitored through perioperative clinical observation of skin colour, temperature, capillary refill and bleeding characteristics, and reassessed after pedicle folding and placement inside the newly tailored skin envelope. Nonvital NAC, as evaluated by the surgeon during surgery, necessitated conversion to the free nipple graft technique.

RESULTS: During the course of the study, two patients (four breasts; $3.03 \%$ ) exhibited impending gangrene to the NAC, and perioperative conversion to the free nipple graft was performed. In these two patients, the pedicle length ranged from $23 \mathrm{~cm}$ to $25 \mathrm{~cm}$, and breast mass reduction ranged from $1950 \mathrm{~g}$ to $2250 \mathrm{~g}$.

CONCLUSION: Perioperative conversion to a free nipple-areola graft is always a good and safe option when impending gangrene to the NAC is evident during mammaplasty by inferior pedicle technique.

Key Words: Complications of mammaplasty; Inferior pedicle; Nipple necrosis; Pedicle length; Reduction mammaplasty

W omen with extremely large and ptotic breasts have many complaints. Reduction mammaplasty improves breast shape and relieves physical complaints that include chronic neck, shoulder and upper back pain (1).

Presently, there are a number of techniques for reduction mammaplasty, because there is no single ideal method for correction of breasts of all sizes (2); no one technique is superior to the others in all aspects (3). Currently, the majority of these techniques include a nipple-bearing pedicle and, of these, the inferior pedicle technique is commonly used in hypertrophic and ptotic breasts of various sizes; it has a very low risk to viability of the nipple-areolar complex (NAC) (3-7).

Pedicle techniques include the superior pedicle, described by Weiner, the vertical pedicle technique by McKissock, the

\section{Viabilité du pédicule comme facteur déterminant de la conversion au greffon de mamelon libre}

INTRODUCTION : Les femmes aux seins extrêmement volumineux présentent de nombreux symptômes. La réduction mammaire permet d'améliorer la forme et de soulager les symptômes physiques, tout en atténuant les plaintes psychologiques. La mammoplastie est une technique en évolution. Aucune méthode à elle seule n'est idéale ni ne convient à tous les types de seins. De nombreuses techniques sont proposées pour la réduction mammaire, y compris les techniques par pédicules supérieur, vertical, horizontal, latéral et inférieur (le plus populaire). Même si les techniques de réduction mammaire se perfectionnent depuis 60 ans, des cas de nécrose du complexe mamelon-aréole (CMA) surviennent encore.

OBJECTIF : Évaluer la conversion périopératoire au greffon de mamelon libre afin de prévenir la nécrose du mamelon lorsque la viabilité du pédicule est clairement compromise.

MÉTHODES : Entre janvier 2002 et mars 2006, 66 patientes (132 seins) ont subi une réduction mammaire à l'aide de la technique par pédicule inférieur. Les patientes présentaient une gigantomastie et nécessitaient l'exérèse de plus de $1000 \mathrm{~g}$ de tissu mammaire par côté. L'âge moyen des patientes était de 34,8 ans. Les patientes souffraient de douleurs au cou, aux épaules et au dos et des symptômes psychologiques. Les données quant à la distance entre la fourchette sternale et le mamelon et la distance entre le pli inframammaire et le mamelon ont été notées avant et après l'opération. Le poids des tissus mammaires excisés de chaque côté a été noté. La viabilité du lambeau pédiculé a été soigneusement surveillée par observation clinique périopératoire de la couleur et de la température de la peau, du remplissage capillaire et des caractéristiques de saignement, puis réévaluée après le positionnement du pédicule à l'intérieur de l'enveloppe cutanée nouvellement façonnée. Un CMA non viable de l'avis du chirurgien durant l'intervention a nécessité la conversion à une technique de greffon de mamelon libre.

RÉSULTATS : Durant l'étude, deux patientes (quatre seins, 3,030 \%) ont présenté une menace de gangrène du CMA et le chirurgien a modifié l'intervention en cours de route pour un greffon de mamelon libre. Chez ces deux patientes, la longueur du pédicule variait de $23 \mathrm{~cm}$ à $25 \mathrm{~cm}$ et la masse de tissu mammaire retranchée allait de $1950 \mathrm{~g}$ à $2250 \mathrm{~g}$.

CONCLUSION : La conversion périopératoire vers un greffon mamelonaréole libre est toujours une option valable et sécuritaire en cas de menace de gangrène du CMA durant la mammoplastie par technique du pédicule inférieur.

horizontal pedicle technique by Strombeck, the lateral pedicle technique by Skoog, vertical mammaplasty by Madeleine Lejour, and the inferior pedicle, which is the most popular technique (1-7). The inferior pedicle was described approximately 60 years previously by Aufricht in 1950 (3), and later modified by Ribeiro in 1973 (4), Robbins in 1973 (5), Courtiss and Goldwyn in 1977 (6), and Georgiade in 1979 to 1983 (7). Currently, almost more than a half century later, there is continued reliance on breast amputation and free nipple graft for the treatment of many cases of gigantomastia (8) .

Traditionally, many plastic surgeons believe that pedicle techniques should not be used when more than $1000 \mathrm{~g}$ of tissue per breast will be removed, because the complication rate is

Faculty of Medicine, Baghdad University, Iraq

Correspondence: Dr Al-shaham AA, Department of Surgery, Faculty of Medicine, Universiti Teknologi MARA, 40450 Shah Alam, Selangor

Darul Ehsan, Malaysia. Telephone 0173-666-230,fax 603-55442831,e-mail alialshaham@yahoo.com or alialshaham@salam.uitm.edu.my 
TABLE 1

Preoperative sternal notch-to-nipple distances

\begin{tabular}{lcc}
\hline $\begin{array}{l}\text { Notch-to-nipple } \\
\text { distance, } \mathbf{c m}\end{array}$ & Right breast, $\mathbf{n}$ & Left breast, $\mathbf{n}$ \\
\hline $30-35$ & 2 & 8 \\
$36-40$ & 40 & 38 \\
$41-45$ & 22 & 20 \\
$46-50$ & 2 & 0
\end{tabular}

Total mean: 39.19 Mean: $39.48 \mathrm{~cm} \quad$ Mean: $38.90 \mathrm{~cm}$

Total number of patients $=66$

TABLE 2

Postoperative sternal notch-to-nipple distances

\begin{tabular}{lcc}
\hline $\begin{array}{l}\text { Notch-to-nipple } \\
\text { distance, } \mathbf{c m}\end{array}$ & Right breast, $\mathbf{n}$ & Left breast, $\mathbf{n}$ \\
\hline 18 & 6 & 0 \\
19 & 12 & 16 \\
20 & 12 & 12 \\
21 & 26 & 26 \\
22 & 8 & 10 \\
23 & 2 & 2 \\
Total mean: 20.37 & Mean: $20.36 \mathrm{~cm}$ & Mean: $20.39 \mathrm{~cm}$
\end{tabular}

Total number of patients $=66$

higher, particularly ischemia of the NAC. Rather, the free nipple graft technique is recommended for large-volume reductions as being safer and having lower morbidity $(9,10)$. This option has the advantage of rapid operative time and little blood loss but, unfortunately, leads to a flat breast with poor projection, which is not aesthetically pleasing.

The important factor in deciding whether to continue to perform using the inferior pedicle technique or switch to the free nipple technique is the viability of the pedicle $(11,12)$ because an ischemic pedicle leads to necrosis of the NAC. To avoid this disastrous complication $(13,14)$, perioperative conversion to free nipple graft is a good and safe option if the pedicle viability is grossly compromised in the inferior pedicle technique.

\section{METHODS}

Between January 2002 and March 2006, data from 66 patients (132 breasts) who underwent reduction mammaplasty by a single surgeon in Al-kindy Teaching Hospital (Baghdad, Iraq) were reviewed. The inferior pedicle technique through inverted $\mathrm{T}$ incision was used in all patients.

The patients typically presented with breast gigantism and required more than $1000 \mathrm{~g}$ of breast mass reduction per side. Their age ranged from 21 to 49 years, with a mean age of 34.8 years. Physical complaints included chronic neck, shoulder and upper back pain as well as psychological issues. Examination with the patient in the sitting position revealed extremely hypertrophic, ptotic breasts. Breast length exceeded patient arms and spread on patient thighs in 15 patients. Additional size asymmetry in 11 patients, in the form of breast width, length or bulkiness, was noticed. All patients had shoulder bra grooving and dermatitis, hyperpigmentation and/or erythematous rashes in the inframammary folds. Psychologically, gigantomastia was troublesome and embarrassing for the patients, and the presence of asymmetry heightened this embarrassment.

Mammaplasty procedure, placement of scars and the expected breast mass reduction from each side was explained to
TABLE 3

Preoperative nipple-to-inframammary fold distances (pedicle length)

\begin{tabular}{lcc}
\hline Pedicle length, $\mathbf{c m}$ & Right breast, $\mathbf{n}$ & Left breast, $\mathbf{n}$ \\
\hline $15-16$ & 18 & 23 \\
$17-18$ & 24 & 20 \\
$19-20$ & 11 & 12 \\
$21-22$ & 9 & 7 \\
$23-24$ & 3 & 4 \\
$>24$ & 1 & 0 \\
Total mean: $18.42 \mathrm{~cm}$ & Mean: $18.79 \mathrm{~cm}$ & Mean: $18.13 \mathrm{~cm}$ \\
\hline \multicolumn{2}{l}{ Total number of patients $=66$}
\end{tabular}

Total number of patients $=66$

TABLE 4

Weight of excised breast tissue

\begin{tabular}{lcc}
\hline $\begin{array}{l}\text { Quantity of excised } \\
\text { tissue, } \mathbf{g}\end{array}$ & Right breast & Left breast \\
\hline $1000-1250$ & 34 & 32 \\
$1250-1500$ & 17 & 17 \\
$1500-1750$ & 8 & 9 \\
$1750-2000$ & 6 & 5 \\
$2000-2250$ & 1 & 3 \\
Total mean: $1490.12 \mathrm{~cm}$ & Mean: $1540.95 \mathrm{~g}$ & Mean: $1471.28 \mathrm{~g}$ \\
\hline
\end{tabular}

Total number of patients $=66$

the patients. The expected size of the new breast and the new bra size were also discussed, and written consent was obtained. Topical povidone iodine $10 \%$ was applied to the breast folds seven to 10 days preoperatively.

Before anesthesia was initiated, standard marking for inferior pedicle technique was performed with the patients in the sitting position with their hands on their waists. Data regarding sternal notch-to-nipple distances were recorded before and after the operation (Tables 1 and 2), and inframammary fold-to-nipple distances were recorded preoperatively (Table 3 ). The weights of the excised breast tissue from either side were also recorded (Table 4).

After de-epithelialization, inferior pedicles were dissected in the usual manner, with a base of $8 \mathrm{~cm}$ to $10 \mathrm{~cm}$ at the inframammary line that gradually tapered to encompass the NAC. The breast mass was incised and reflected en bloc with the pre-excised medial and lateral breast segments. Subsequently, the inferior flap was tailored using a diathermy knife to trim the medial and lateral extra segments, leaving the inferior pedicle attached by fibrofatty tissue to the chest wall with the usual thickness of $2 \mathrm{~cm}$ to $4 \mathrm{~cm}$ at the areola end and $6 \mathrm{~cm}$ to $10 \mathrm{~cm}$ at the base end. The excised breast tissue from each breast was measured and recorded. The viability of the inferior pedicle flaps was checked carefully by perioperative clinical observation of skin colour, temperature, capillary refill and bleeding characteristics, and reassessed after pedicle folding and placement of the flap inside the newly tailored skin envelope. A nonvital or grossly ischemic pedicle and nipple, as evaluated by the surgeon during the surgery, necessitated perioperative conversion to the free nipple graft technique. The conversion procedure begins by harvesting the NAC as a free graft from the ischemic pedicle, followed by debridement of the nonvital part of the pedicle by serial excision of tissue slices from the distal part of the flap until healthy tissue is approached. 
In cases of breast asymmetry, uniformity in the design ensures symmetry in the new breast. Principally, the follow-up period ranged from 45 to 120 days, with a mean of 70 days.

\section{RESULTS}

The preoperative and postoperative sternal notch-to-nipple distances are shown in Tables 1 and 2. The breast mass reduction from either side was more than $1000 \mathrm{~g}$ in all patients. The mean mass reductions from either breast are shown in Table 4.

During the course of the study, two patients (four breasts; $3.03 \%$ ) showed signs of impending gangrene of the inferior pedicle and hence the NAC, for which perioperative conversion to the free nipple graft was performed. In this group, the breast mass reduction from either side ranged from $1950 \mathrm{~g}$ to $2250 \mathrm{gm}$, and the pedicle lengths ranged from $23 \mathrm{~cm}$ to $25 \mathrm{~cm}$ (Table 5). Both patients required extraoperative time for conversion ( $1 \mathrm{~h}$ and $1.5 \mathrm{~h}$, respectively).

In total, the inferior pedicle length distances (nipple-toinframammary fold distances) ranged from $15 \mathrm{~cm}$ to $25 \mathrm{~cm}$, with a mean of $18.79 \mathrm{~cm}$ in the right breast and $18.13 \mathrm{~cm}$ in the left breast (Table 3).

The mean upward transposition of the NAC was $19.12 \mathrm{~cm}$ in the right breast and $18.51 \mathrm{~cm}$ in the left breast.

All patients expressed marked improvement in neck, back, shoulder and breast pain as well as improvement in inframmamary pigmentation and rash. All patients reported better self-confidence and improved psychological well-being.

The follow-up period ranged from 45 to 120 days, with a mean of 70 days.

\section{DISCUSSION}

To our knowledge, there are few studies correlating pedicle length with the viability of the inferior pedicle $(11,12)$. Furthermore, few studies propose therapeutic guidelines for situations in which the surgeon is faced with mild ischemia to the NAC flap; a literature review did not reveal any studies that identified the critical length of inferior pedicle in mammaplasty. Information regarding the management of grossly compromised flaps is scarce. Among the pedicle techniques, the inferior pedicle technique is considered to be safe regardless of the degree of parenchymal resection. Another advantage of this technique is the relatively easy reproducibility and short learning curve $(15,16)$. The disadvantages include long incision scars, potential skin necrosis and dehiscence at the inverted $\mathrm{T}$ base $(17,18)$.

All patients in the present study underwent reduction mammaplasty using the inferior pedicle technique. Large reduction volumes are not contraindications to using the inferior pedicle technique $(1,19)$.

Despite the advances in breast reduction techniques, and better understanding of breast circulation, vascular-dependent necrosis of the NAC following reduction mammaplasty is still reported (13) regardless of whether the flap is based superiorly, inferiorly or both. The rate of perioperative conversion into free nipple graft in the present case series study was 3.030\%. Two patients (four breasts) showed unrecoverable ischemia to the nipple-areola flap; the recorded lengths of the inferior pedicles involved ranged from $23 \mathrm{~cm}$ to $25 \mathrm{~cm}$, and the breast mass reduction from either breast ranged from $1950 \mathrm{~g}$ to $2250 \mathrm{~g}$ (Table 5). This cannot be explained on the basis of long

\section{TABLE 5}

Data of the conversion group

\begin{tabular}{lrc}
\hline & Patient 1 & Patient 2 \\
\hline Right breast & & \\
Pedicle length, cm & 25 & 23 \\
Breast mass reduction, g & 2250 & 1950 \\
Left breast & & \\
Pedicle length, cm & 24 & 24 \\
Breast mass reduction, g & 2100 & 2150 \\
\hline
\end{tabular}

pedicles per se, which already sustained subclinical ischemia during dissection. However, further folding and placement in the newly created envelope during closure will compound the viability and ultimately lead to nipple necrosis. Individual vascular variability may play an additional role in determining the extent of ischemia.

The actual reported incidence of partial or total necrosis is widely variable, ranging from $0.4 \%$ to $6 \%$. Chang et al (20) reported the least incidence of nipple necrosis in their study of 172 patients who underwent breast reduction by inferior pedicle technique. In their study, the mean total breast mass reduction was $1946 \mathrm{~g}$, and the survival rate of the NAC was 99.6\%. In another study, Mandrekas et al (17) reviewed 371 consecutive patients who underwent reduction mammaplasty by inferior pedicle technique. The reported incidence of nipple or pedicle necrosis was $0.8 \%$. Nahabedian and Mofid (21) reported total viability of the NAC in 74 of 79 breasts (94\%) after medial pedicle reduction mammaplasty and viability of the NAC in 53 of 54 breasts (98\%) after inferior pedicle reduction mammaplasty.

Although the occurrence of NAC necrosis is infrequent, it is a disastrous complication that greatly impairs the result of the mammaplasty, and is of great concern to the patient and the surgeon alike (22).

The crucial point in deciding on the conversion to free nipple graft is the unequivocal clinical signs of inadequate blood flow. Although conversion to a free graft is always a safe option, the aesthetic result is usually inferior. Studies evaluating objective monitoring to maximize the surgical outcome and decrease the risk of nipple necrosis, such as Doppler flowmetry or laser Doppler to continuously evaluate nipple perfusion during and after surgery have concluded that these tools would be helpful; however, nothing can replace the surgeon's skill and judgment (23).

The main drawback of conversion to free nipple-areola graft is the prolongation of surgical time during conversion. In the present study, the extra time required ranged between $1 \mathrm{~h}$ and $1.5 \mathrm{~h}$.

\section{CONCLUSION}

Perioperative conversion to free nipple-areola graft is a good and safe option when impending gangrene to the NAC is evident during mammaplasty, by inferior pedicle technique. Further studies are warranted to identify the critical length of the inferior pedicle.

FUNDING: The present study did not receive any form of support (local or international) or grant. All surgical procedures were performed at Al-kindy Teaching Hospital (Baghdad, Iraq). 


\section{REFERENCES}

1. Boschert MT, Barone CM, Puckett CL. Outcome analysis of reduction mammaplasty. Plast Reconstr Surg 1996;98:451-4.

2. Adams Jr WP, Shewmake KB. Reduction mammaplasty and mastopexy. Selected Readings in Plast Surg J 1998;29:8-16.

3. Aufricht G. Mammoplasty for pendulous breasts. Plast Reconstr Surg J 1949;4:13.

4. Ribeiro L. A new technique for reduction mammaplasty. Plast Reconstr Surg 1975;55:330-4.

5. Robbins TH. A reduction mammaplasty with the areola-nipple based on a inferior dermal pedicle. Plast Reconstr Surg 1977;59:64-7.

6. Courtiss EH, Goldwyn RM. Reduction mammaplasty by the inferior pedicle technique. An alternative to free nipple and areola grafting for severe macromastia or extreme ptosis. Plast Reconstr Surg 1977;59:500-7.

7. Georgiade NG, Serafin D, Morris R, Georgiade G. Reduction mammaplasty utilizing an inferior pedicle nipple-areolar flap. Ann Plast Surg 1979;3:211-8.

8. Strömbeck JO. Reduction mammaplasty. Surg Clin North Am 1971;51:453-69.

9. Hawtof DB, Levine M, Kapetansky DI, Pierper D. Complications of reduction mammaplasty: Comparison of nipple-areolar graft and pedicle. Ann Plast Surg 1989;23:3-10.

10. Zubowski R, Zins JE, Foray-Kaplon A, et al. Relationship of obesity and specimen weight to complications in reduction mammaplasty. Plast Reconstr Surg 2000;106:998-1003.

11. Jackson IT, Bayramicli M, Gupta M, Yavuzer R. Importance of the pedicle length measurement in reduction mammaplasty. Plast Reconstr Surg 1999;104:398-400.

12. Erdogan B, Ayhan M, Deren O, Tunsel A. Importance of pedicle length in inferior pedicle technique and long-term outcome of areola-to-fold distance. Aesthet Plast Surg 2002;26:436-43.
13. Calderon W, Eulufi A, Borel C, Léniz P, Calderon D. Total nipple-areola complex necrosis in inferior pedicle breast reduction. Plast Reconstr Surg 2006;118:292-3.

14. Wray RC, Luce EA. Treatment of impending nipple necrosis following reduction mammaplasty. Plast Reconstr Surg 1998;65:242-4.

15. Koger KE, Sunde D, Press BH, Hoovey LR. Reduction mammaplasty for gigantomastia using inferiorly based pedicle and free nipple transplantation. Ann Plast Surg 1994;33:561-4.

16. O'Grady KF, Thoma A, Dal Cin A. A comparison of complication rates in large and small inferior pedicle reduction mammaplasty. Plast Reconstr Surg 2006;118:274-5.

17. Mandrekas AD, Zambacos GJ, Anastasopoulos A, Hapsas DA. Reduction mammaplasty with the inferior pedicle technique: Early and late complications in 371 patients. Brit J Plast Surg 1996;49:442-6.

18. Georgiade GS, Riefkohl RE, Georgiade NG. The inferiordermalpyramidal type breast reduction: Long-term evaluation. Ann Plast Surg 1989;23:3-10.

19. Schur PL, Schur DP, Petty PM, Hanson TT. Reduction mammaplasty; an outcome study. Plast Reconstr Surg 1997;100:875-83.

20. Chang P, Shaaban AF, Canady JW, Ricciardelli EJ, Cram AE. Reduction mammaplasty: The results of avoiding nipple-areolar amputation in cases of extreme hypertrophy. Aesthet Plast Surg 2008;32:307-12.

21. Nahabedian MY, Mofid MM.Viability and sensation of the nipple-areolar complex after reduction mammaplasty. Ann Plast Surg 2002;49:24-32.

22. Hallock GG. Salvage by tattooing of areolar complications following breast reduction. Plast Reconstr Surg 1993;91:942-5.

23. Hallock GG. Prediction of nipple viability following reduction mammoplasty using laser Doppler flowmetry. Ann Plast Surg 1992;29:457-60. 